Poul J. Jennum, MD, Dr Med Sci

Birgitte R. Kornum, PhD

Nadia M. Issa, MD

Steen Gammeltoft, MD, Dr Med Sci

Niels Tommerup, MD,

Dr Med Sci

Niels Morling, MD, Dr Med Sci

Zeynep Tümer, MD, Dr Med Sci

Stine Knudsen, MD, PhD

Neurol Neuroimmunol

Neuroinflamm

2016;3:e249; doi: 10.1212/ NXI.0000000000000249

\section{MONOZYGOTIC TWINS DISCORDANT FOR NARCOLEPSY TYPE 1 AND MULTIPLE SCLEROSIS \\ OPEN}

Narcolepsy type 1 (NC1) is a neurologic sleep disorder caused by the loss of hypothalamic neurons that produce the sleep-wake regulating neuropeptides, the hypocretins (orexins). The pathogenesis is believed to be mainly autoimmune, based on the observation of a $95 \%$ to 100\% association with the HLA-DQB1*06:02 allele, and on the recent strong indication of antigen presentation to $\mathrm{T}$ cells as central factors. ${ }^{1}$ In Caucasians and Asians, the DQB1*06:02 allele is tightly linked to the HLA-DRB1*15:01 allele, which itself is associated with multiple sclerosis (MS), a CNS autoimmune disorder. Herein, we describe a DRB1*15:01/DQB1*06:02positive monozygotic twin pair discordant for $\mathrm{NC1}$ and MS.

Case report. In 2004, a 34-year-old, otherwise healthy Caucasian man (twin A) was diagnosed with narcolepsy $\mathrm{NC1}, 19$ years after the onset of sleepiness. At the time of diagnosis, he presented severe daytime sleepiness (Epworth Sleepiness Scale score of 22/24), hypnagogic hallucinations, and dream enactment during sleep (REM sleep behavior disorder), but no cataplexy or sleep paralyses. Sleep investigations confirmed narcolepsy: the polysomnography was normal except for REM sleep without atonia, which was consistent with the reported dream enactment; the Multiple Sleep Latency Test showed a mean sleep latency of 6 minutes, with sleep-onset REM periods in 4 of 4 naps. He was hypocretin-deficient (CSF hypocretin-1: $58 \mathrm{pg} / \mathrm{mL}$, compared with normal levels of $\geq 200$ $\mathrm{pg} / \mathrm{mL}$ ) and his HLA type was DRB1*15:01/13:01; DQB1*06:02/06:03. In 2008, cataplexy triggered by laughter and surprise evolved. In 2011, serologic tests confirmed Epstein-Barr/cytomegaloviral infection and he experienced temporary leg paraesthesia, from which he quickly and fully recovered. Neurologic examinations, MRI of the brain and spinal cord, and measurement of the immunoglobulin $\mathrm{G}(\mathrm{IgG})$ index gave normal results. Oligoclonal bands were absent. The low CSF hypocretin-1 level was unchanged.

In 2006, his brother (twin B) was healthy, with a normal Epworth Sleepiness Scale score (8/24) and no narcoleptic symptoms. He declined to participate in sleep investigations, but was confirmed to be DRB1*15:01/13:01; DQB1*06:02/06:03-positive. In 2010, he developed bilateral hand/forearm paraesthesia. MRI of the brain and neck revealed $>9$ demyelinating periventricular lesions and a hyperintense lesion at the C2 level. Definite MS was diagnosed according to the 2010 revised McDonald criteria ${ }^{2}$ after an additional clinical attack, an elevated $\mathrm{IgG}$ index (1.22), and the presence of oligoclonal bands in the CSF. The CSF hypocretin-1 level was normal $(283 \mathrm{pg} / \mathrm{mL})$. He confirmed that he experienced "tiredness" (fatigue), but reported no sleep attacks or other core narcoleptic symptoms. As narcolepsy was not suspected and because he had a severe crisis reaction after his MS diagnosis, we refrained from undertaking a sleep investigation.

The DNA was typed for monozygosity using 16 polymorphic microsatellite (short tandem repeat) markers: D1S1656, D2S441, D2S1338, D3S1358, D8S1179, D10S1248, D12S391, D16S539, D18S51, D19S433, D21S11, D22S1045, FGA, SE33, TH01, vWA, and the sex marker Amelogenin (AmpFLSTR NGM Select PCR Amplification kit; ThermoFisher Scientific, Waltham, MA). The likelihood ratio in favor of monozygosity was greater than $10,000: 1$.

Discussion. The present case is notable for several reasons. Monozygotic twin pairs discordant for $\mathrm{NC1}$ and MS are rare. The presence of MS - an autoimmune CNS disorder - in the genetically identical twin of a hypocretin-deficient patient with narcoleptic supports the pathophysiologic importance of the recently found association between $\mathrm{NC1}$ and genes involved in antigen processing, presentation, and T cell response. ${ }^{1}$

Comorbid autoimmune disease ${ }^{3}$ and cases of comorbid MS have been observed in single cases of sporadic NC1 and, notably, in an H1N1-vaccinated $\mathrm{NC1}$ patient. ${ }^{4}$ We have previously reported that sleepiness and hypocretin levels are generally normal in MS, ${ }^{5}$ but secondary hypocretin deficiency and hypersomnia/NC1 have been reported in a few cases of neuromyelitis optica. ${ }^{6}$ The NC1- and MSpredisposing HLA-DRB1*15:01/DQB1*06:02 haplotype is also found in approximately $25 \%$ of the general population. Several other predisposing genes, 
none of which overlap, have been reported and account for some of the missing heritability in both diseases. However, the present monozygotic twin A, who, when last examined, still had isolated NC1 without signs of comorbid MS, and twin B, who still had isolated MS without signs of secondary $\mathrm{NC1}$, had an asymptomatic DRB1*15:01/DQB1*06:02 homozygote father and an asymptomatic DRB1*15:01/DQB1*06:02-negative mother. This strongly suggests that a shared genetic background of DRB1*15:01/DQB1*06:02 is not sufficient to account for a predisposition to either of these autoimmune CNS disorders. Additional predisposing genes are most likely uncommon since comorbidity is rare, but environmental factors, for example, bacterial or viral infections, are believed to be equally important in the pathogenesis of autoimmune disorders. Pandemrix is a vaccine whose effect is reduced in patients with MS treated with immunomodulatory drugs such as glatiramer acetate or natalizumab but not in patients on interferon $\beta .^{7}$ Given the dramatic increase of $\mathrm{NC1}$ cases following H1N1 vaccinations with Pandemrix (GlaxoSmithKline), our present twin case and cases of comorbid MS and NC1 after $\mathrm{H} 1 \mathrm{~N} 1$ vaccination $^{4}$ could be valuable for further studies of the genetic background and specific triggers (or drivers) of autoimmunity in these CNS disorders.

From the Danish Center for Sleep Medicine (P.J.J., S.K.) and Molecular Sleep Laboratory, Department of Clinical Biochemistry (B.R.K., S.G.), University of Copenhagen, Rigshospitalet, Glostrup, Denmark; Norwegian Centre of Expertise for Neurodevelopmental Disorders and Hypersomnias (NevSom) (S.K.), Oslo University Hospital, Ullevål, Norway; Department of Neurology (N.M.I.), University of Copenhagen, Hillerod Hospital; Department of Cellular and Molecular Medicine, Panum Institute (N.T.), and Section of Forensic Genetics, Department of Forensic Medicine, Faculty of Health and Medical Science (N.M.), University of Copenhagen; Applied Human Molecular Genetics (Z.T.), Kennedy Center, Department of Clinical Genetics, Copenhagen University Hospital, Rigshospitalet, Glostrup, Denmark.

Author contributions: S.K., P.J.J., B.R.K., and S.G. designed the study. S.K. and N.M.I. handled patients and CSF/blood samples. P.J.J. analyzed the sleep investigation data. S.G. and S.K. measured the hypocretin levels. N.T., N.M., and Z.T. handled the genetic samples and designed and performed the genetic tests. S.K., P.J.J., and B.R.K. wrote the manuscript. Z.T., N.M.I., and N.M. revised the manuscript.

Study funding: No targeted funding.

Disclosure: P.J. Jennum's institution received a research grant from UCB. B.R. Kornum received research support from UCB. N.M. Issa, S. Gammeltoft, N. Tommerup, and N. Morling report no disclosures. $Z$. Tümer received research support from the Lundbeck Foundation. $S$. Knudsen served as a member of the scientific panel for sleep disorders, received research support from and served as an expert consultant for the Norwegian State. Go to Neurology.org/nn for full disclosure forms. The Article Processing charge was paid by Norwegian Centre of Expertise for Neurodevelopmental Disorders and Hypersomnias.

This is an open access article distributed under the terms of the Creative Commons Attribution-NonCommercial-NoDerivatives License 4.0 (CC BY-NC-ND), which permits downloading and sharing the work provided it is properly cited. The work cannot be changed in any way or used commercially.

Received February 27, 2016. Accepted in final form May 6, 2016.

Correspondence to Dr. Knudsen: stinkn@ous-hf.no

1. Faraco J, Lin L, Kornum BR, et al. ImmunoChip study implicates antigen presentation to $\mathrm{T}$ cells in narcolepsy. PLoS Genet 2013;9:e1003270.

2. Polman $\mathrm{CH}$, Reingold SC, Banwell B, et al. Diagnostic criteria for multiple sclerosis: 2010 revisions to the McDonald criteria. Ann Neurol 2011;69:292-302.

3. Martinez-Orozco FJ, Vicario JL, Villalibre-Valderrey I, De Andrés C, Fernandez-Arquero M, Peraita-Adrados R. Narcolepsy with cataplexy and comorbid immunopathological diseases. J Sleep Res 2014;23:414-419.

4. Vrethem M, Malmgren K, Lindh J. A patient with both narcolepsy and multiple sclerosis in association with Pandemrix vaccination. J Neurol Sci 2012;321:89-91.

5. Knudsen S, Jennum PJ, Korsholm K, Sheikh SP, Gammeltoft S, Frederiksen JL. Normal levels of cerebrospinal fluid hypocretin-1 and daytime sleepiness during attacks of relapsing-remitting multiple sclerosis and monosymptomatic optic neuritis. Mult Scler 2008;14:734-738.

6. Kanbayashi T, Shimohata T, Nakashima I, et al. Symptomatic narcolepsy in patients with neuromyelitis optica and multiple sclerosis: new neurochemical and immunological implications. Arch Neurol 2009;66:1563-1566.

7. Olberg HK, Cox RJ, Nostbakken JK, Aarseth JH, Vedeler CA, Myhr KM. Immunotherapies influence the influenza vaccination response in multiple sclerosis patients: an explorative study. Mult Scler 2014;20:1074-1080. 


\section{Neurology \\ Neuroimmunology \& Neuroinflammation}

Monozygotic twins discordant for narcolepsy type 1 and multiple sclerosis

Poul J. Jennum, Birgitte R. Kornum, Nadia M. Issa, et al.

Neurol Neuroimmunol Neuroinflamm 2016;3;

DOI 10.1212/NXI.0000000000000249

This information is current as of June 16, 2016

\section{Updated Information \& Services}

References

Citations

Subspecialty Collections

Permissions \& Licensing

Reprints including high resolution figures, can be found at:

http://nn.neurology.org/content/3/4/e249.full.html

This article cites 7 articles, 0 of which you can access for free at: http://nn.neurology.org/content/3/4/e249.full.html\#\#ref-list-1

This article has been cited by 1 HighWire-hosted articles: http://nn.neurology.org/content/3/4/e249.full.html\#\#otherarticles

This article, along with others on similar topics, appears in the following collection(s):

Autoimmune diseases

http://nn.neurology.org//cgi/collection/autoimmune_diseases

Class IV

http://nn.neurology.org//cgi/collection/class_iv

Multiple sclerosis

http://nn.neurology.org//cgi/collection/multiple_sclerosis

Narcolepsy

http://nn.neurology.org//cgi/collection/narcolepsy

Information about reproducing this article in parts (figures,tables) or in its entirety can be found online at:

http://nn.neurology.org/misc/about.xhtml\#permissions

Information about ordering reprints can be found online:

http://nn.neurology.org/misc/addir.xhtml\#reprintsus

Neurol Neuroimmunol Neuroinflamm is an official journal of the American Academy of Neurology.

Published since April 2014, it is an open-access, online-only, continuous publication journal. Copyright $(\subseteq$ 2016 American Academy of Neurology. All rights reserved. Online ISSN: 2332-7812.

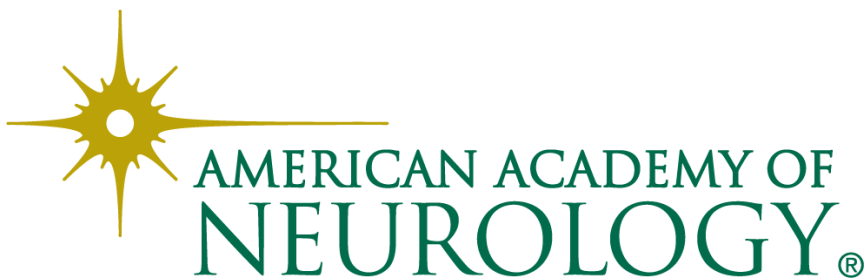

